\title{
RANCANG BANGUN SISTEM PENDUKUNG KEPUTUSAN UNTUK PEMILIHAN LAPTOP DENGAN METODE DECISION TREE
}

\author{
Dedi Anggaradana \\ Program Studi Sistem Komputer, STMIK STIKOM, Bali \\ dediajust@gmail.com
}

\begin{abstract}
A very rapid development of technology makes the laptop seems to have not a luxury anymore. Those with high mobility and frequent travel, choose the laptop as something that accompanies every job they wherever they went. But not a few consumers who are hesitant and confused when trying to buy a new laptop since the laptop is not cheap stuff. Moreover currently popping up various types of laptops with different specs and brand, any price varies. Not infrequently the consumer to buy a laptop with good specs without thinking about its usefulness.

For that it is necessary a decision support system for laptop malakukan selection process effectively and efficiently. Decision support system is an interactive system that supports the decision in the decision making process through the alternative - the alternative obtained from the data processing, information and design models.

Making an online decision support system using the decision tree method is able to resolve the election issue this laptop, with a step - step method is simple, easily understood, effective and efficient. With the web-based decision support system will be the technology that not only provides convenience, but able to provide solutions to an individual in choosing the right laptop and also fit your needs and budget.
\end{abstract}

Keywords : System, Decision Support, Decision Tree

\begin{abstract}
ABSTRAK
Perkembangan teknologi yang sangat pesat membuat laptop sepertinya sudah bukan menjadi barang mewah lagi. Mereka yang mobilitasnya tinggi dan sering bepergian, memilih laptop sebagai benda yang menemani setiap pekerjaan mereka kemanapun mereka pergi. Namun tak sedikit konsumen yang bimbang dan kebingungan saat ingin membeli laptop baru mengingat laptop bukanlah barang murah. Terlebih lagi saat ini bermunculan berbagai jenis laptop dengan beragam spesifikasi dan merk, pun harganya bervariasi. Tak jarang pula konsumen membeli laptop dengan spesifikasi yang bagus tanpa memikirkan kegunaannya.

Untuk itu sangat diperlukan suatu sistem pendukung keputusan untuk malakukan proses pemilihan laptop secara efektif dan efisien. Sistem pendukung keputusan merupakan suatu sistem interaktif yang mendukung keputusan dalam proses pengambilan keputusan melalui alternatif - alternatif yang diperoleh dari hasil pengolahan data, informasi dan rancangan model.

Pembuatan suatu sistem pendukung keputusan secara online dengan menggunakan metode decision tree mampu menyelesaikan untuk persoalan pemilihan laptop ini, dengan langkah - langkah metode ini yang sederhana, mudah dipahami, efektif dan efisien. Dengan adanya sistem pendukung keputusan berbasis web ini akan menjadi teknologi yang tidak hanya memberikan kemudahan, namun mampu memberikan solusi kepada seseorang dalam memilih laptop yang tepat dan juga sesuai dengan kebutuhan dan anggaran.
\end{abstract}

Kata kunci : Sistem, Pendukung Keputusan, Decision Tree 



\section{PENDAHULUAN}

Dengan berkembangnya pemakaian perangkat lunak di dalam segala bidang kehidupan di masyarakat, bentukbentuk pemakaian sistem kerja dengan komputer juga menjadi semakin berkembang. Sistem kerja dengan komputer tidak lagi hanya di gunakan sekedar untuk mengolah data dan menyajikan informasi, namun hasil dari proses yang diolah dapat juga digunakan untuk mendukung pemecahan suatu masalah atau pendukung pengambilan keputusan dengan berbagai alternatif yang tersedia.

Hasil yang di berikan oleh sistem sebagai pendukung keputusan dapat memberikan suatu alternatif pemecahan masalah bagi para pemakainya, dengan memberikan berbagai kemungkinan hasil sesuai dengan kondisi parameter masalah yang dapat berubah. Hal ini akan dapat memberikan berbagai alternatif pemecahan masalah yang ada, sehingga keputusan yang dibuat menjadi lebih baik dan lebih mudah.

Sering kali orang membeli laptop tanpa pengetahuan dasar tentang komponenkomponen dasar yang ada di dalamnya atau sering kali dikatakan spesifikasinya (spec). Maka banyak ditemui orang yang membeli laptop dengan spec yang tinggi, merek terkenal, dan harga yang begitu mahal, tetapi pada akhirnya tidak sesuai dengan penggunaanya. Atau sebaliknya, memilih harga yang murah, tetapi akhirnya tidak bisa memenuhi kebutuhan yang diinginkannya. Akan lebih baik sebelum memilih sebuah laptop, Maka kita harus memperhatikan kebutuhan kita dan budget yang ada sehingga kita tidak salah pilih.

Oleh karena itu, kita membutuhkan suatu analisis untuk pendukung pengambilan keputusan dalam pemilihan laptop yang dapat menghasilkan keputusan dari berbagai alternatif yang ada dalam memilih suatu produk laptop. Sistem pendukung keputusan untuk pemilihan produk laptop ini akan menggunakan suatu metode yang disebut decision tree yaitu suatu analisis pohon keputusan.

Dari kondisi di atas maka penulis melakukan penelitian untuk membuat suatu sistem dengan judul "Rancang Bangun Sistem Pendukung Keputusan Untuk Pemilihan Laptop dengan Metode Decision Tree". Maka dengan sistem ini diharapkan mampu memberikan kemudahan dan membantu konsumen dalam pengambilan keputusan untuk pemilihan laptop berdasarkan kebutuhan. Adapun software yang digunakan yaitu Macromedia Dreamweaver 8.

\section{TINJAUAN PUSTAKA}

\section{Sistem Pendukung Keputusan (SPK)}

Sistem pendukung keputusan

(SPK) atau dikenal dengan Decision Support System (DSS), pada tahun 1970-an sebagai pengganti istilah Management Information Sys-tem (MIS). Tetapi pada dasarnya SPK me-rupakan pengembangan lebih lanjut dari MIS yang dirancang sedemikian rupa sehingga bersifat interaktif dengan pemakainya.

Maksud dan tujuan dari adanya SPK, yaitu untuk mendukung pengambil keputusan memilih alternatif keputusan yang merupakan hasil pengolahan informasi-informasi yang diperoleh/tersedia dengan menggunakan model-model pengambil keputusan serta untuk menyelesaikan masalah-masalah bersifat terstruktur, semi terstruktur dan tidak terstruktur.

Pada dasarnya pengambilan keputusan adalah suatu pendekatan sistematis pada suatu masalah, pengumpulan fakta dan informasi, penentuan yang baik untuk alternatif yang dihadapi, dan pengambilan tindakan yang menurut analisis merupakan tindakan yang paling tepat. Tetapi pada sisi yang berbeda, pembuat keputusan kerap kali dihadapkan pada kerumitan dan lingkup keputusan dengan data yang cukup banyak. Untuk kepentingan itu, sebagian besar pembuat keputusan dengan mempertimbangkan rasio manfaat/biaya, dihadapkan pada suatu keharusan untuk mengandalkan sistem yang mampu memecahkan suatu masalah secara efisien dan efektif, yang kemudian disebut dengan Sistem Pendukung Keputusan (SPK).

Dengan memperhatikan tinjauan relatif atas peranan manusia dan komputer untuk mengetahui bidang fungsi masing-masing, keunggulan serta kelemahannya, maka memahami SPK dan pemanfaatannya sebagai sistem yang menunjang dan mendukung pengambilan keputusan dapat dilakukan dengan baik. Tujuan pembentukan SPK yang efektif adalah memanfaatkan keunggulan kedua unsur, yaitu manusia dan perangkat elektronik. Terlalu banyak menggunakan komputer akan menghasilkan pemecahan suatu masalah yang bersifat mekanis, reaksi yang tidak fleksibel, dan keputusan yang 
dangkal. Sedangkan terlalu banyak manusia akan memunculkan reaksi yang lamban, pemanfaatan data yang serba terbatas, dan kelambanan dalam mengkaji alternatif yang relevan.

\section{Pengertian Sistem Pendukung Keputusan}

Persoalan pengambilan keputusan, pada dasarnya adalah bentuk pemilihan dari berbagai alternatif tindakan yang mungkin dipilih yang prosesnya melalui sebuah mekanisme. Dan alternatif tindakan yang mungkin terjadi akan disesuaikan dengan kondisi persoalan yang dihadapi. Pada umumnya para penulis buku pendukung keputusan sependapat bahwa kata keputusan (decision) berarti pilihan (choice), yaitu pilihan dari dua atau lebih kemungkinan. Pengambilan keputusan hampir tidak merupakan pilihan antara yang benar dan yang salah tetapi justru yang sering terjadi adalah pilihan antara yang "hampir benar" dan yang "mungkin salah". Keputusan yang diambil biasanya dilakukan berdasarkan pertimbangan situasional, bahwa keputusan tersebut adalah keputusan terbaik.

Walaupun keputusan biasa dikatakan sama dengan pilihan, ada perbedaan penting diantara keduanya. Sementara para pakar melihat bahwa keputusan adalah "pilihan nyata" karena pilihan diartikan sebagai pilihan tentang tujuan termasuk pilihan tentang cara untuk mencapai tujuan itu, baik pada tingkat perorangan atau pada tingkat kolektif. Selain itu, keputusan dapat dilihat pada kaitannya dengan proses, yaitu bahwa suatu keputusan ialah keadaan akhir dari suatu proses yang dinamis yang diberi label pengambilan keputusan.

Keputusan dipandang sebagai proses karena terdiri atas satu seri aktivitas yang berkaitan dan tidak hanya dianggap sebagai tindakan bijaksana. Dengan kata lain, keputusan merupakan sebuah kesimpulan yang dicapai sesudah dilakukan pertimbangan, yang terjadi setelah satu kemungkinan dipilih, sementara yang lain dikesampingkan. Dalam hal ini, yang dimaksud dengan pertimbangan ialah menganalisis beberapa kemungkinan atau alternatif, lalu memilih satu diantaranya.

Definisi SPK menunjukkan SPK sebagai sebuah sistem yang dimaksudkan untuk mendukung para pengambil keputusan manajerial dalam situasi keputusan semistruktur. SPK dimaksudkan untuk menjadi alat bantu bagi para pengambil keputusan untuk memperluas kapabilitas mereka, namun tidak untuk menggantikan penilaian mereka. SPK ditunjukkan untuk keputusan-keputusan yang memerlukan penilaian atau pada keputusan-keputusan yang sama sekali tidak dapat didukung oleh algoritma. Ciri-ciri serta keuntungan dalam menggunakan SPK dapat dituliskan sebagai berikut :

1. Dapat menyelesaikan masalah yang kompleks.

2. Sistem dapat berinteraksi dengan pemakainya, sehingga dapat membuat alternatif lebih dulu.

3. Lebih cepat dan dengan hasil yang lebih baik dibanding dengan pengambilan keputusan yang intuisi (mengandalkan perasaan) terutama untuk lingkungan yang cepat berubah.

4. Menghasilkan acuan data untuk menyelesaikan masalah yang dihadapi bagi manajer yang kurang berpengalaman.

5. Untuk masalah yang berulang, SPK dapat memberi keputusan dengan lebih efektif meski tidak selalu lebih efisien.

6. Fasilitas untuk mengambil data dapat memberi beberapa manajer berkomunikasi dengan lebih baik.

7. Meningkatkan produktifitas dan kontrol dari manajer.

8. Membantu bermacam-macam bagian dari manajemen.

9. SPK didesain untuk mudah dibuat dan mudah dipakai.

10. SPK digunakan untuk "membantu" manajer sehingga setiap saat dapat diabaikan atau dibatalkan.

\section{Metode Decision Tree (Pohon Keputusan)}

Pohon keputusan merupakan metode klasifikasi dan prediksi yang sangat kuat dan terkenal. Metode pohon keputusan mengubah fakta yang sangat besar menjadi pohon keputusan yang merepresentasikan aturan. Aturan dapat dengan mudah dipahami dengan bahasa alami. Dan mereka juga dapat diekspresikan dalam bentuk bahasa basis data seperti Structured Query Language untuk mencari record pada kategori tertentu.

Pohon keputusan juga berguna untuk mengeksplorasi data, menemukan hubungan tersembuyi antara sejumlah calon variabel input dengan sebuah variabel target. Karena pohon keputusan memadukan 
antara eksplorasi data dan pemodelan, dan sangat bagus sebagai langkah awal dalam proses pemodelan bahkan ketika dijadikan sebagai model akhir dari beberapa teknik lain (Kusrini, 2009).

\section{Dasar-dasar Decision Tree}

Secara konsep decision tree adalah salah satu dari teknik decision analysis. Tries sendiri pertama kali diperkenalkan pada tahun 1960-an oleh Fredkin. Trie atau digital tree berasal dari kata retrival (pengambilan kembali) sesuai dengan fungsinya. Secara etimologi kata ini diucapkan sebagai tree. Meskipun mirip dengan kata try, tetapi hal ini bertujuan untuk membedakannya dari general tree. dalam ilmu komputer, trie atau prefix tree adalah sebuah struktur data dengan representasi ordered tree yang digunakan untuk menyimpan associative array yang berupa string. Berbeda dengan binary search tree (BST) yang tidak ada node di tree yang menyimpan elemen yang berhubungan dengan node sebelumnya dan posisi setiap elemen di tree sangat menentukan. Semua keturunan dari suatu node mempunyai prefix string yang mengandung elemen dari node itu, dengan root merupakan string kosong. Values biasanya tidak terkandung di setiap node, hanya di daun dan beberapa node di tengah yang cocok dengan elemen tertentu.

Secara singkat bahwa decision tree merupakan salah satu metode klasifikasi pada text mining. Klasifikasi adalah proses menemukan kumpulan pola atau fungsi-fungsi yang mendeskripsikan dan memisahkan kelas data satu dengan lainnya, untuk dapat digunakan untuk memprediksi data yang belum memiliki kelas data tertentu (Jianwei Han, 2001).

Pohon keputusan dikembangkan untuk membantu pengambil keputusan membuat serangkaian keputusan yang melibatkan peristiwa ketidakpastian. Pohon keputusan adalah suatu peralatan yang mengambarkan secara grafik berbagai kegiatan yang dapat diambil dan dihubungkan dengan kegiatan ini dengan berbagai peristiwa di waktu mendatang yang dapat terjadi. Seperti dalam teknik riset operasi, pohon keputusan tidak akan membuat keputusan bagi pengambil keputusan, kebijakan masih akan diperlukan. Bagaimanapun dalam berbagai situasi yang tepat, penggunaan pohon keputusan akan mengurangi kekacauan potensial dalam suatu masalah kompleks dan memungkinkan pengambil keputusan menganalisis masalah secara rasional (Sutabri, 2005).

Sebuah pohon keputusan adalah sebuah struktur yang dapat digunakan untuk membagi kumpulan data yang besar menjadi himpunan-himpunan record yang lebih kecil dengan menerapkan serangkaian aturan-aturan keputusan. Dengan masing-masing rangkaian pembagian, anggota himpunan hasil menjadi mirip satu dengan yang lain (Berry dan Linnof, 2004).

\section{Prosedur Pembentukan Decision Tree}

Decision tree adalah sebuah struktur pohon, dimana setiap node pohon merepresentasikan atribut yang telah diuji, setiap cabang merupakan suatu pembagian hasil uji, dan node daun (leaf) merepresentasikan kelompok kelas tertentu. Level node teratas dari sebuah decision tree adalah node akar (root) yang biasanya berupa atribut yang paling memiliki pengaruh terbesar pada suatu kelas tertentu. Pada umumnya decision tree melakukan strategi pencarian secara top- down untuk solusinya. Pada proses mengklasifikasi data yang tidak diketahui, nilai atribut akan diuji dengan cara melacak jalur dari node akar (root) sampai node akhir (daun) dan kemudian akan diprediksi kelas yang dimiliki oleh suatu data baru tertentu.

Sebuah model keputusan terdiri dari sekumpulan aturan untuk membagi jumlah populasi yang heterogen menjadi lebih kecil, lebih homogen dengan memperhatikan pada variabel tujuannya. Sebuah model keputusan mungkin dibangun dengan saksama secara manual atau dapat tumbuh secara otomatis dengan menerapkan salah satu atau beberapa algoritma pohon keputusan untuk memodelkan himpunan data yang belum terklasifikasi (Kusrini, 2009).

Variabel tujuan biasanya dikelompokkan dengan pasti dan model pohon keputusan lebih mengarah pada perhitungan probabilitas dari tiap-tiap record terhadap kategori-kategori tersebut atau untuk mengklasifikasi record dengan mengelompokkannya dalam satu kelas. Pohon keputusan juga dapat digunakan untuk mengestimasi nilai dari variabel continue meskipun ada beberapa teknik yang lebih sesuai untuk kasus ini.

Data dalam pohon keputusan biasanya dinyatakan dalam bentuk tabel dengan atribut dan record. Atribut 
menyatakan suatu parameter yang dibuat sebagai kriteria dalm pembentukan pohon keputusan. Misalkan untuk menentukan main tenis, kriteria yang diperhatikan adalah cuaca, angin, dan temperatur. Salah satu atribut merupakan atribut yang menyatakan data solusi per item data yang disebut target atribut. Atribut memliki nilai-nilai yang dinamakan dengan instance. Misalkan atribut cuaca mempunyai instance berupa cerah, berawan dan hujan (Basuki dan Syarif, 2003).

\section{ANALISA DAN DESAIN SISTEM}

Dalam perancangan website ini penulis mempergunakan Macromedia Dreamweaver 8 sebagai pembuatan website, sedangkan perancangan database menggunakan MySQL sebagai penyimpanan, dan apache digunakan sebagai web server.

\section{Context Diagram}

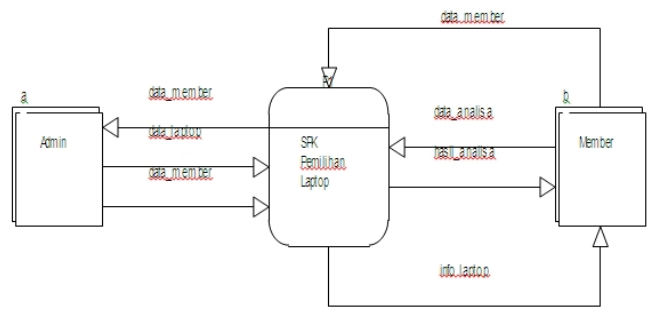

Gambar 1 Context Diagram

Keterangan :

Context Diagram dari alur Sistem Pendukung Keputusan Pemilihan Laptop Dengan Metode Decision Tree. Di sistem ini terdapat entitas member dan admin yang berhubungan langsung dengan Sistem Pendukung Keputusan Pemilihan Laptop Dengan Metode Decision Tree. Pada member, data yang diinputkan berupa data member dan data analisa. Sedangkan dari sistem, member mendapatkan hasil analisa dan info laptop. Pada entitas admin, sistem memberikan data member ke admin.

\section{Data Flow Diagram (DFD)}

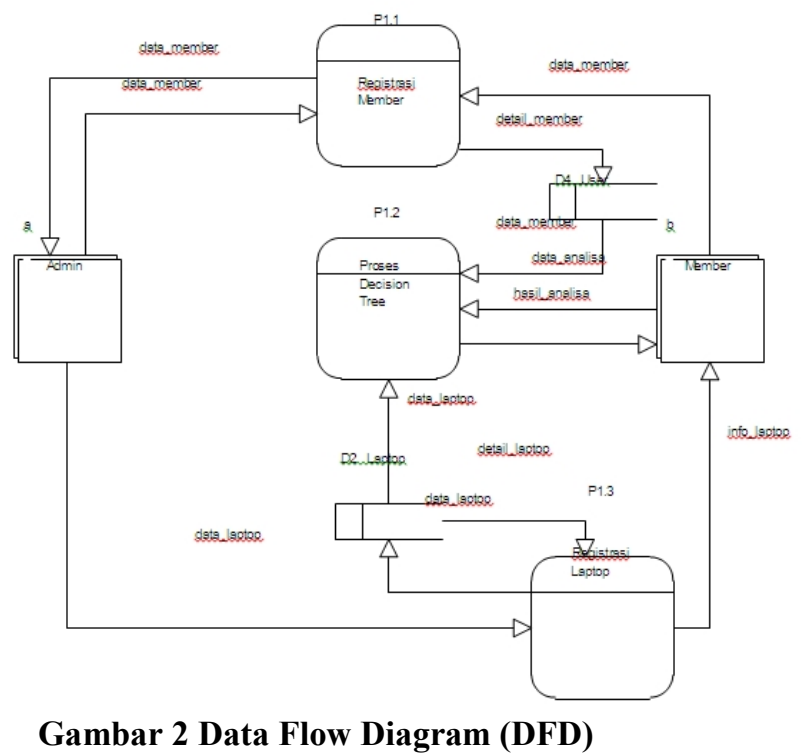

Keterangan :

Pada Data Flow Diagram (DFD), Context Diagram akan dipecah menjadi 3 tahapan yaitu Registrasi Member, Proses Decision Tree, dan Registrasi Laptop. Hal ini bertujuan untuk memudahkan dalam mengetahui tahapan-tahapan apa saja yang ada di dalam sistem ini. Data laptop akan diinputkan dan di edit melalui admin. Setelah itu barulah member dapat melihat informasi data produk.

\section{IMPLEMENTASI SISTEM \\ Implementasi}

Menu utama Sistem Pendukung Keputusan Untuk Pemilihan Laptop Dengan Metode Decision Tree yang ada di halaman utama (index) adalah sebagai berikut :

\section{Halaman Utama (Index) \\ Halaman Home}

Halaman Home, merupakan halaman yang pertama kali muncul pada saat masuk ke website Sistem Pendukung Keputusan Untuk Pemilihan Laptop Dengan Metode Decision Tree.

Pada halaman ini berisikan tombol Home, Profil, Berita, Produk, Hubungi Kami serta Registrasi yang akan link ke halaman selanjutnya sesuai dengan tombol tersebut. Di halaman ini juga terdapat berita atau informasi dan tips-tips seputar tentang laptop. 


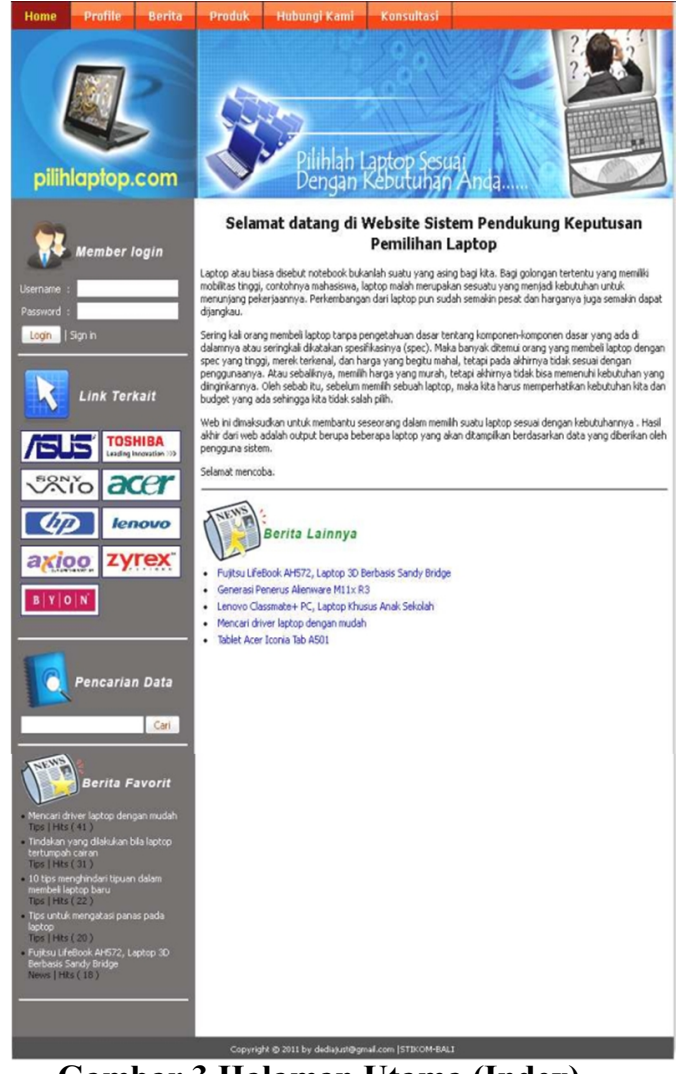

Gambar 3 Halaman Utama (Index)

\section{Halaman Profil}

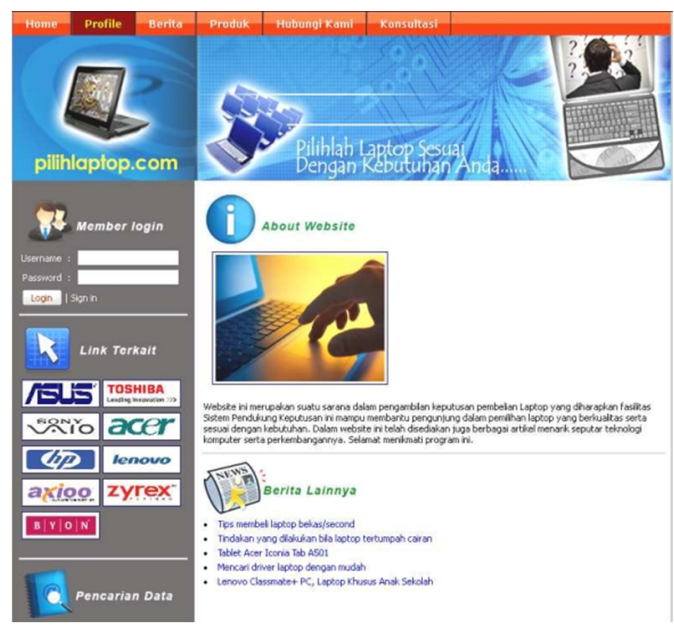

\section{Gambar 4 Halaman Profil}

Pada halaman ini terdapat profil dari perusahaan pengembangan website serta tujuan website ini dibuat.

\section{Halaman Berita}

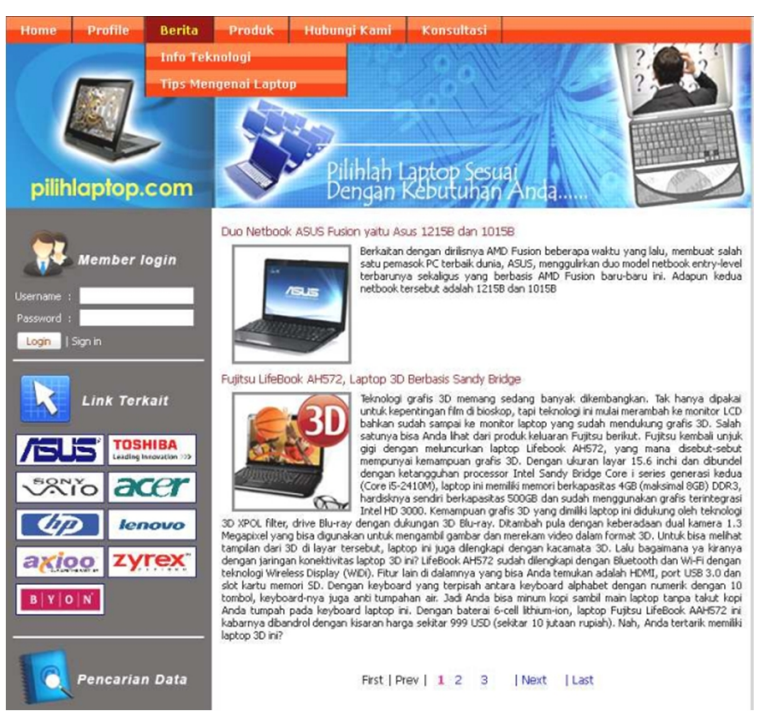

Gambar 5 Halaman Berita

Pada halaman ini terdapat berita-berita maupun tips terkini seputar teknologi dunia laptop dan akan terupdate secara berkala.

\section{Halaman Produk Laptop}

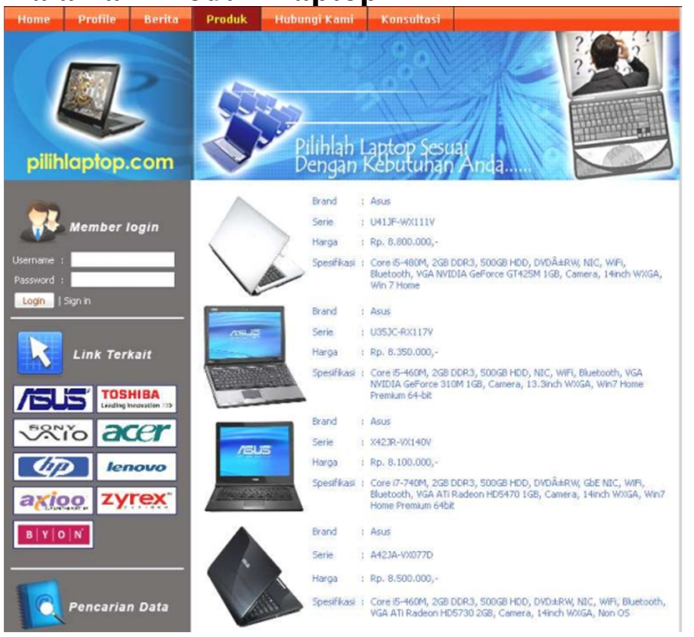

Gambar 6 Halaman Produk Laptop

Halaman Produk merupakan halaman yang nenyajikan informasi-informasi produk laptop yang diberikan. Pada halaman ini pengunjung website hanya dapat melihat produk laptop tanpa melakukan konsultasi. Konsultasi hanya dapat dilakukan setelah pengunjung melakukan registrasi untuk menjadi member, dan setelah menjadi member barulah login untuk masuk ke halaman konsultasi untuk menjawab beberapa pertanyaan. 
Halaman Hubungi Kami

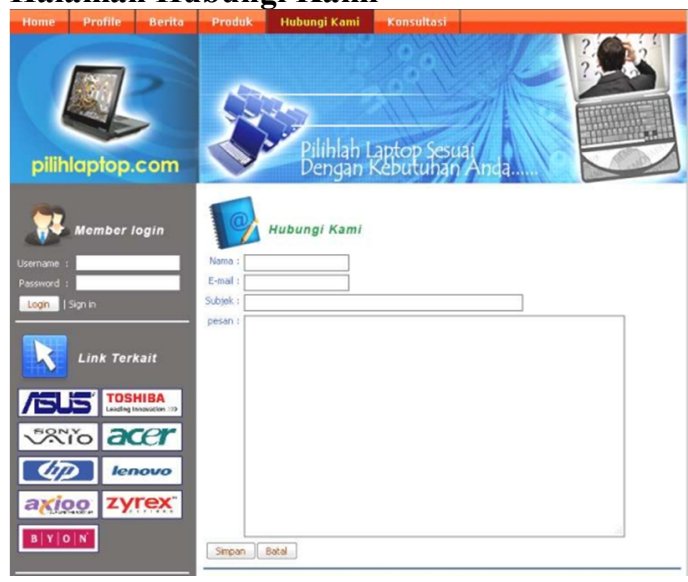

Gambar 7 Halaman Hubungi Kami

Pada halaman ini member pengunjung (user) dapat mengisi form hubungi kami untuk dihubungi oleh admin. Sama halnya seperti buku tamu, user bisa mengajukan pertanyaan, saran maupun kritik di form ini.

\section{Halaman Konsultasi}

Halaman konsultasi ini dapat diakses setelah member melakukan login. Halaman ini menampilkan beberapa daftar pertanyaan yang akan dijawab oleh member, dari hasil pertanyaan berikut kemudian disimpan dan dicocokan sehingga menghasilkan keputusan beberapa laptop bagi member.

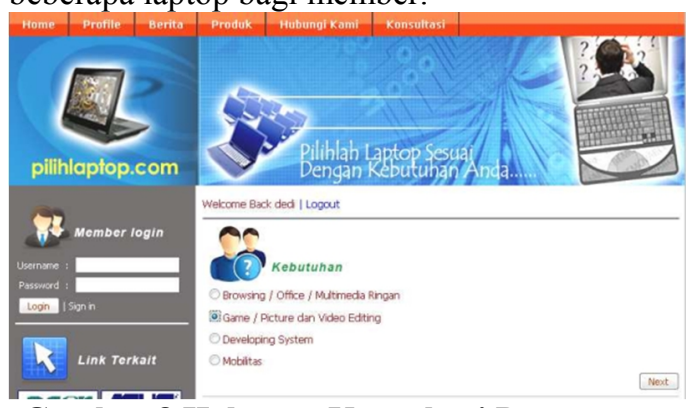

Gambar 8 Halaman Konsultasi Pertama

Pada halaman diatas, menampilkan pertanyaan berupa kebutuhan prioritas member tersebut dalam membeli suatu laptop.

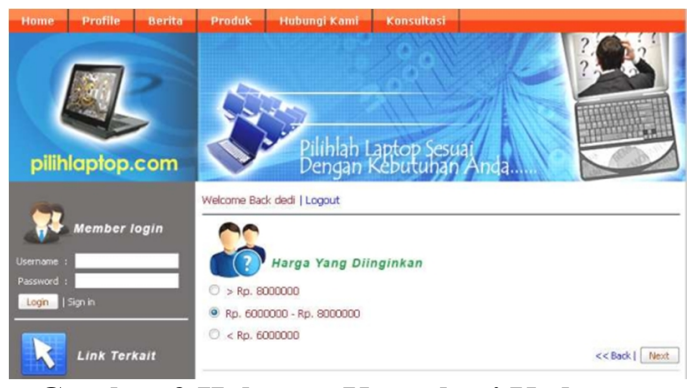

Gambar 9 Halaman Konsultasi Kedua
Pada halaman diatas, menampilkan pertanyaan berupa budget member tersebut dalam membeli suatu laptop.

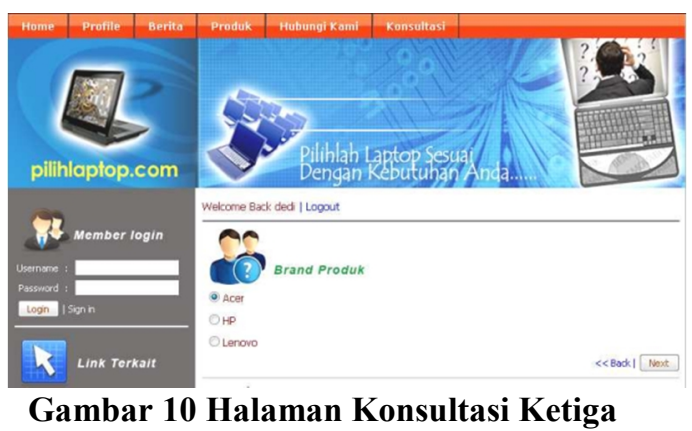

Pada halaman diatas, menampilkan pertanyaan berupa merk laptop yang diinginkan oleh member.

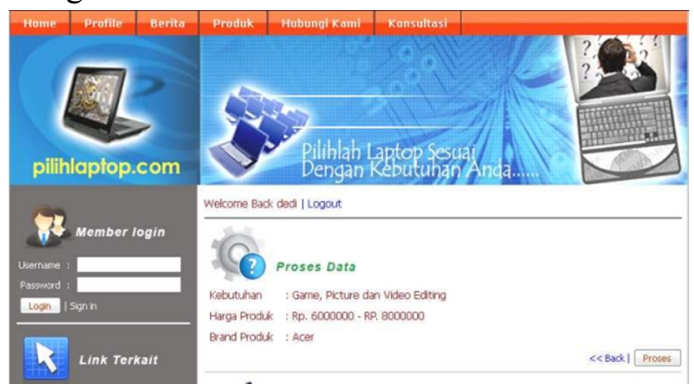

Gambar 11 Halaman Proses

Pada halaman diatas, menampilkan suatu kesimpulan member dalam yang memilih suatu laptop berupa kebutuhan, harga dan merek yang nantinya selanjutnya akan diproses.

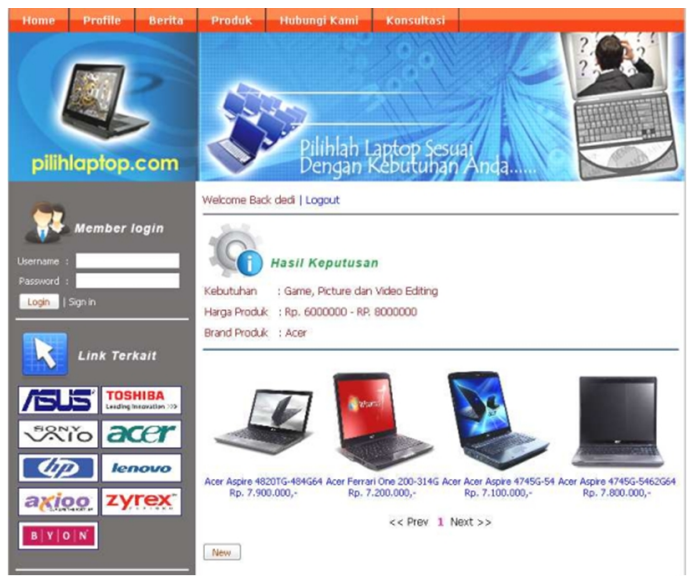

Gambar 12 Halaman Hasil Keputusan

Pada halaman diatas, menampilkan suatu hasil keputusan dari Sistem Pendukung Keputusan Pemilihan Laptop yang akan direkomendasikan kepada member. 


\section{Halaman Statistik}

Pada halaman ini menampilkan statistik atau diagram persentase dari kebutuhan dan merk dari setiap laptop yang sudah dilakukan oleh para member sebelumnya pada website tersebut.

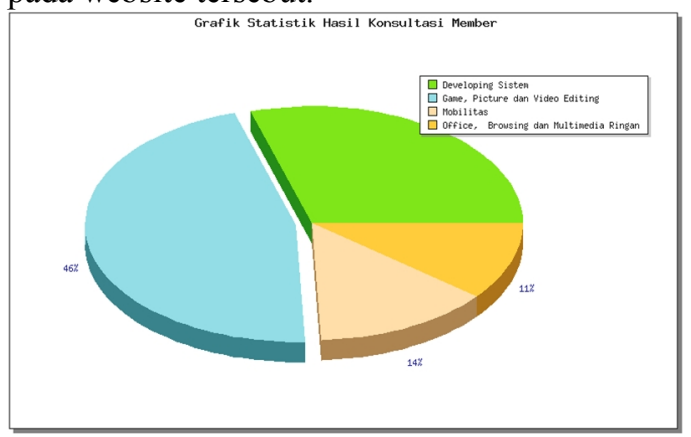

Gambar 13 Halaman Statistik Kebutuhan

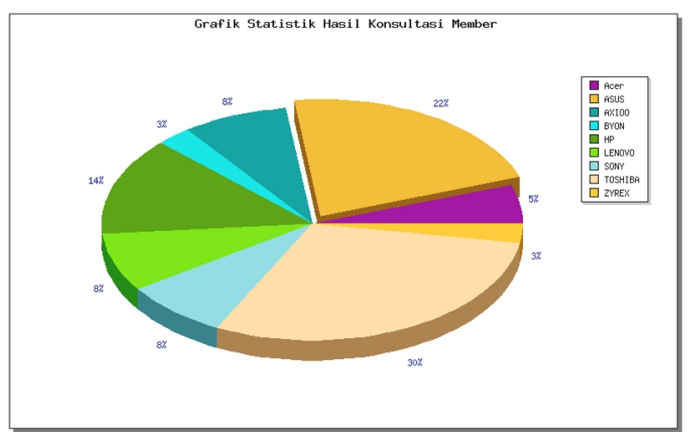

Gambar 14 Halaman Statistik Merk Laptop

\section{Halaman Registrasi}

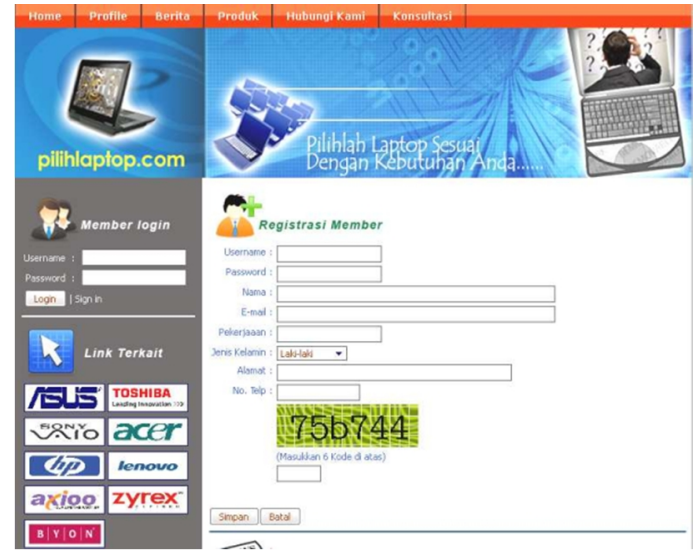

Gambar 15 Halaman Registrasi

Di halaman ini pengunjung (user) disajikan form registrasi atau pendaftaran menjadi member. Dimana data yang akan diinputkan oleh user diantaranya username, password, nama lengkap, email, pekerjaan jenis kelamin, alamat dan telepon/handphone. Data ini akan digunakan untuk melakukan login sehingga dapat melakukan pemilihan laptop.

\section{Halaman Utama (Admin)}

Menu utama Admin Sistem Pendukung Keputusan Untuk Pemilihan Laptop Dengan Metode Decision Tree yang ada di halaman utama (index) adalah sebagai berikut :

\section{Halaman Login Administrator}

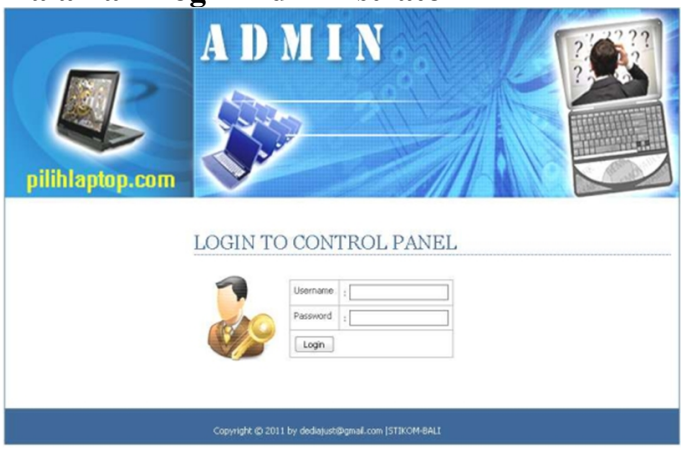

Gambar 16 Halaman Login Administrator

Untuk dapat masuk ke halaman Admin diharuskan login terlebih dahulu, jika username atau password yang dimasukkan tidak sesuai dengan data yang tersimpan maka akan tampil pesan error, dan bila username dan password benar maka akan masuk ke halaman utama administrator.

\section{Halaman Utama Administrator}

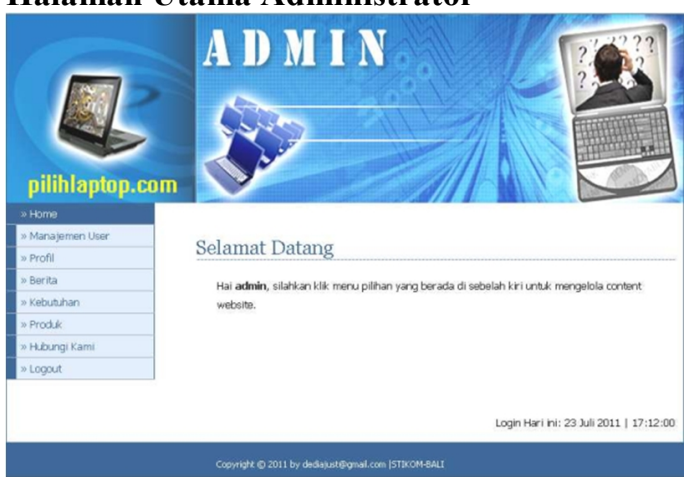

\section{Gambar 17 Halaman Home} Administrator

Halaman utama administrator merupakan halaman home yang tampil apabila admin sudah melakukan login. 


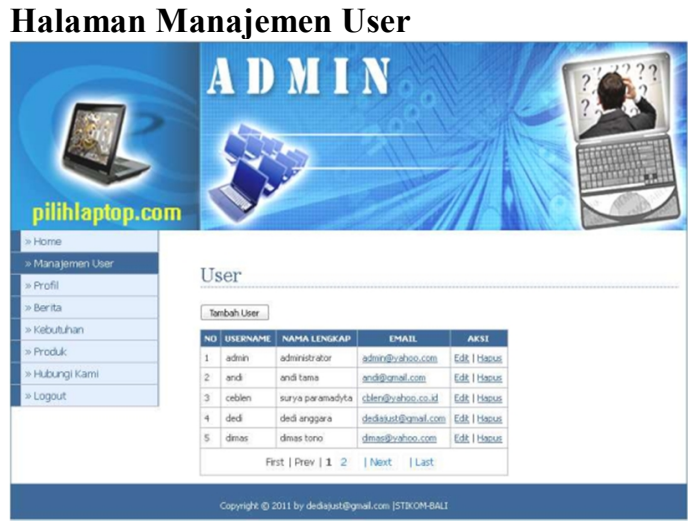

\section{Gambar 18 Halaman Manajemen User}

Halaman manajemen user berisikan data admin maupun member yang bisa ditambah, diedit, maupun dihapus.

\section{Halaman Profil}

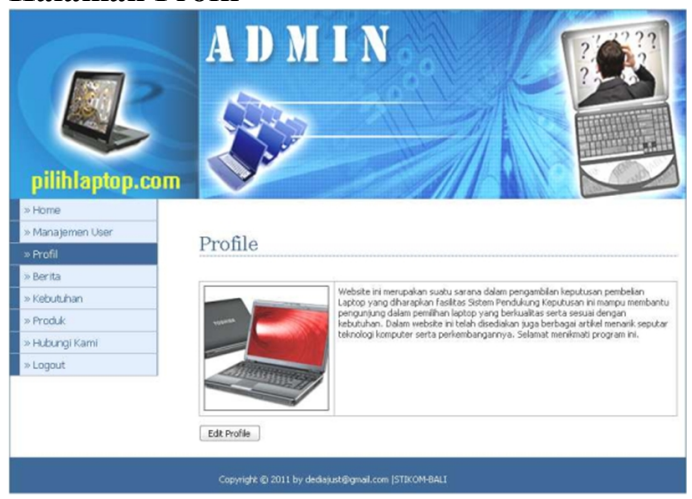

Gambar 19 Halaman Profil

Pada halaman profil merupakan halaman untuk mengedit profil yang dilakukan oleh admin yang nantinya akan muncul pada menu profil user.

\section{Halaman Berita}

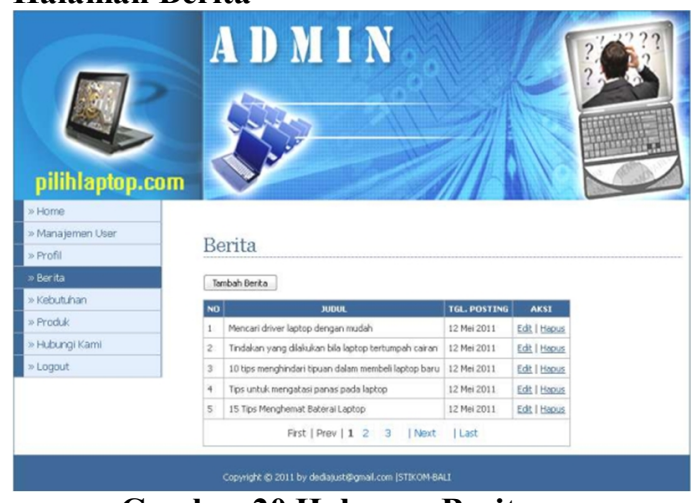

Gambar 20 Halaman Berita

Pada halaman berita merupakan halaman untuk mengedit, menghapus, maupun menambahkan suatu berita yang dilakukan oleh admin yang nantinya akan muncul pada menu berita user.

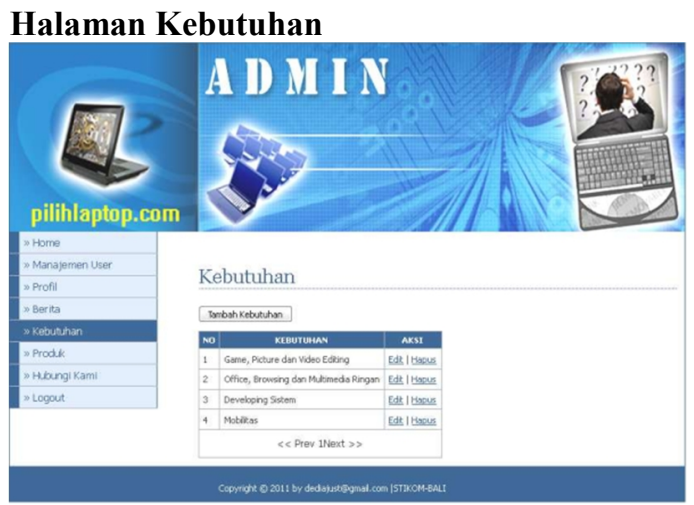

\section{Gambar 21 Halaman Kebutuhan}

Pada halaman kebutuhan merupakan halaman untuk mengedit, menghapus, maupun menambahkan suatu kebutuhan laptop yang dilakukan oleh admin yang nantinya akan muncul pada menu konsultasi user.

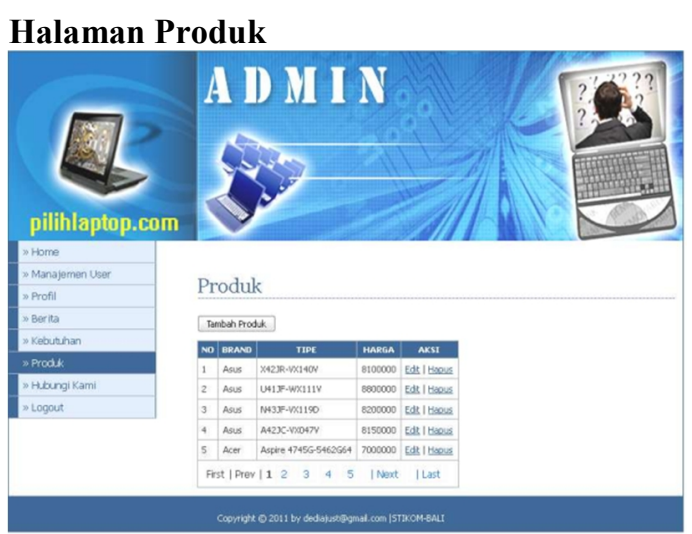

Gambar 22 Halaman Produk

Pada halaman ini terdapat data produk laptop yang dapat diedit, dihapus, maupun ditambah data produk laptop yang baru.

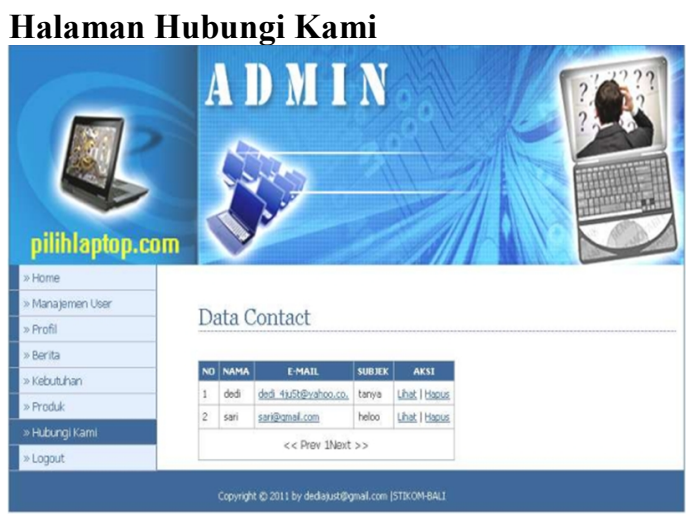

Gambar 23 Halaman Hubungi Kami

Halaman ini berisi informasi dari user yang mengisi form hubungi kami atau buku tamu. 


\section{SIMPULAN}

Kesimpulan yang diperoleh dari hasil perancangan dan pembuatan sistem pendukung keputusan ini adalah :

1. Web ini merupakan suatu sarana dalam pengambilan keputusan pembelian laptop yang diharapkan fasilitas sistem pendukung keputusan ini mampu membantu seseorang dalam pemilihan laptop yang berkualitas serta sesuai dengan kebutuhannya.

2. Sistem berbasis web ini, mempermudah para user dalam memperoleh informasi dan mengakses data secara online.

\section{DAFTAR PUSTAKA}

[1] Han, Jiawei dan Micheline Kamber. Data Mining : Concept and Techniques. San Fransisco. Morgan Kauffman Publishers, 2001.

[2] Jogiyanto, Analisis dan Desain Sistem Informasi, Andi offset, Yogyakarta. 1989. Kadarsah, Suryadi. Sistem Pendukung Keputusan, PT Remaja Rosdakarya, Bandung.

[3] Narbuko Cholid dan Achmadi Abu. Metodologi Penelitian, Bumi Aksara, Jakarta, 2002.

[4] Arbie, Manajemen Database dengan MySQL, Andi, Yogyakarta, 2004.

[5] Juju, Dominkus. Tips dan Trik Desain Web Untuk Pemula, Bogor: PT ElexMedia Komputindo, 2006.

[6] Simarmata,Jannet. Panduan Cepat Menggunakan Dreamweaver MX, Yogyakarta: Andi Yogyakarta, 2005. 